\title{
Pengaruh Penambahan Konsentrasi Tapioka Terhadap Mutu Sensori dan Nutrisi Produk Otak-otak Ikan Madidihang (Thunnus albacares)
}

\section{The Effect of Addition of Tapioca Concentration on Sensory Quality and Nutrition of Yellowfin Tuna (Thunnus albacares) Otak-otak Products}

\author{
Abdul Azis Iskandar Alam, Aisyah Bafagih, Vanessa Natalie Jane Lekahena* \\ Prodi Teknologi Hasil Perikanan, Universitas Muhammadiyah Maluku Utara \\ "Email: enchalekahena@gmail.com
}

\begin{abstract}
Yellowfin tuna (Thunnus albacares) is an economically important fish and fishery export commodity. This fish has meat with high protein content and is the low-fat content, as well as some essential minerals for health. Nutritional content in yellowfin meat causes the meat to be processed in various processing products, and one of them is the product of otak-otak products. The fish otak-otak products are a modified processed product made from white fish with the addition of starch, coconut milk, egg whites, and spices, which are wrapped lengthwise in banana leaves and then steamed, roasted, and fried. The purpose of this study was to examine the optimal concentration of tapioca on the nutritional and sensory content of yellowfin fish paste products. This study used a single factor completely randomized design, namely the concentration of tapioca $(0 \%, 25 \%, 50 \%$, and $75 \%)$. The results of this study indicate that the addition of tapioca concentrations does not affect the sensory quality of the products of fish paste products in the appearance attributes of 5.02-6.30; textures 4.96-6.24; aroma 5.40-6.40 and taste 5.126.54 , meanwhile the nutritional content of otak-otak products is strongly influenced by the added tapioca concentration with moisture content range of 46.45-69.78\%; ash 0.98-1.83\%; protein 5.65-26.38\%; fat $0.94-1.56 \%$ and carbohydrates $0.77-45.37 \%$. The best otak-otak product at $50 \%$ tapioca concentration $\left(\mathrm{PO}_{2}\right)$ with the nutritional content of $15.76 \%$ protein, $1.28 \%$ ash and $0.94 \%$ fat.
\end{abstract}

Keywords: Nutrition, sensory, tapioca flour, otak-otak products

\begin{abstract}
Abstrak
Ikan madidihang (Thunnus albacares) merupakan jenis ikan ekonomis penting dan komoditas ekspor perikanan. Jenis ikan ini memiliki daging dengan kandungan protein yang tinggi dan rendah lemak, serta sejumlah mineral penting bagi kesehatan. Kandungan gizi yang baik pada daging ikan madidihang menyebab dagingnya banyak diolah dalam berbagai jenis olahan, dan salah satunya adalah produk otakotak. Otak-otak merupakan modifikasi produk olahan yang terbuat dari ikan berdaging putih dengan penambahan tepung, santan, putih telur dan bumbu-bumbu, yang dibungkus memanjang dengan daun kemudian dikukus dipanggang dan digoreng. Tujuan penelitian ini untuk mengkaji tentang konsentrasi tapioka yang optimal terhadap kandungan nutrisi dan sensori otak-otak ikan madidihang. Penelitian ini menggunakan rancangan acak lengkap faktor tunggal yaitu konsentrasi tapioka $(0 \%, 25 \%, 50 \%$ dan $75 \%$ ). Hasil dari penelitian ini menunjukkan bahwa penambahan konsentrasi tapioka tidak berpengaruh terhadap mutu sensori produk otak-otak pada atribut kenampakan 5,02-6,30; tekstur 4,96-6,24; aroma 5,40-6,40 serta rasa 5,12-6,54, sementara untuk kandungan nutrisi produk otak-otak sangat dipengaruhi oleh konsentrasi tapioka yang ditambahkan dengan kisaran nilai kadar air 46,45-69,78\%; abu 0,981,83\%; protein 5,65-26,38\%; lemak 0,94-1,56\% dan karbohidrat 0,77-45,37\%. Produk otak-otak terbaik pada konsentrasi tapioka 50\% $\left(\mathrm{PO}_{2}\right)$ dengan kandungan nutrisi kadar protein 15,76\%, abu 1,28\% dan lemak $0,94 \%$.
\end{abstract}

Kata kunci: Nutrisi, sensori, tapioka, produk otak-otak 


\section{PENDAHULUAN}

Ikan madidihang (Thunnus albacares) adalah jenis ikan ekonomis penting dan merupakan komoditas ekspor dari sektor perikanan Indonesia, yang memiliki nilai jual walaupun tanpa dilakukan proses pengolahan lanjutan. Data perikanan tangkap Propinsi Maluku Utara per Agustus Tahun 2019, melaporkan produksi ikan tuna sebesar 165.754 ton/tahun (Tranformasi, 2019).

Ikan madidihang memiliki kandungan protein yang tinggi dan lemak yang rendah. Secara utuh bagian dari tubuh jenis ikan ini terdiri dari $59,7 \%$ daging, tulang $30,23 \%$, jeroan $7,65 \%$, dan kulit $4,21 \%$, dengan kandungan gizi berupa $25,86 \%$ protein, $1,21 \%$ lemak, $0.60 \%$ abu dan sejumlah mineral seperti kalsium, fosfor, besi dan sodium (Nurjanah dkk, 2020). Daging ikan madidihang memiliki proporsi terbesar dari keseluruhan tubuh ikan, dengan kandungan gizi $71,73 \%$ kadar air, $1,48 \%$ abu, $28,34 \%$ protein, dan $0,51 \%$ lemak (Hadinoto dan Idrus, 2018). Tingginya kandungan protein pada daging ikan madidihang menyebabkan mudah mengalami kemunduran mutu, sehingga diperlukan proses penanganan, pengawetan, pengolahan atau diversifikasi olahan untuk mempertahankan mutu.

Diversifikasi olahan produk perikanan adalah upaya untuk meningkatkan dan mengoptimal nilai pemanfaatan produksi hasil tangkapan laut dalam produk yang bernilai tambah baik secara tradisional maupun modern. Bentuk diversifikasi olahan berbahan dasar daging ikan madidihang yang telah dilakukan adalah bakso ikan dengan penambahan rumput laut (Lekahena, 2015), nugget ikan (Thalib, 2011), sambal ikan tuna (Poernomo dkk., 2019), serta berbagai jenis olahan lainnya.

Produk otak-otak merupakan salah satu bentuk diversifikasi olahan berbahan dasar ikan. Produk ini merupakan modifikasi produk olahan yang terbuat dari ikan berdaging putih dengan penambahan tepung, santan, putih telur dan bumbu-bumbu, yang dibungkus memanjang dengan daun kemudian dikukus dipanggang dan digoreng (Karim dkk., 2013). Pengolahan produk otak-otak dengan menggunakan beberapa jenis ikan telah dilakukan seperti ikan sapu-sapu (Nurjanah dkk., 2005), ikan kurisi (Putra dkk., 2015), ikan gabus (Jamil, 2016), dan ikan tenggiri (Ramlawati dan Ramli, 2018), serta berbagai jenis ikan lainnya. Pada penelitian ini pengolahan otak-otak ikan menggunakan daging ikan madidihang sebagai bahan dasar pembuatan otak-otak ikan.

Proses pengolahan produk otak-otak atau produk berbahan dasar pasta ikan biasanya menggunakan tapioka sebagai bahan pengisi dan pengikat, karena mengandung pati (amylum) dan berfungsi untuk menjaga stabilitas emulsi, menurunkan penyusutan akibat pemasakan, memberi warna yang terang, meningkatkan elastisitas produk, membentuk tekstur yang padat, dan menarik air dalam adonan (Ramlawati \& Ramli, 2018), sehingga dapat berpengaruh terhadap sifat sensori dan nutrisi produk yang dihasilkan. Tujuan dari penelitian adalah mengkaji tentang penambahan konsentrasi tapioka yang optimal terhadap kandungan nutrisi dan sensori otakotak ikan madidihang, sedangkan manfaat penelitian ini diharapkan menjadi sumber informasi ilmiah dalam bidang pengolahan hasil perikanan dan sebagai bahan masukan bagi petani dan pengolah hasil perikanan tentang komposisi produk otak-otak ikan madidihang.

\section{METODOLOGI}

\section{Alat dan Bahan}

Alat yang digunakan adalah alat pengolahan seperti talenan, pisau, timbangan, wajan, blender, sendok, kompor, dandang, dan pemanggangan. Selain itu, digunakan alat analisis seperti oven vakum, tanur pengabuan, soxlet lemak dan cawan porselin, pipet, erlenmeyer, buret, gelas ukur, perangkat analisis protein kjedhal, dan desikator, serta alat tulis menulis. Bahan yang digunakan untuk persiapan sampel berupa daging ikan madidihang, daun pisang, garam, bawang merah, bawang putih, santan kelapa, lengkuas dan tapioka, sedangkan bahan untuk analisis proksimat terdiri dari $\mathrm{H}_{2} \mathrm{SO}_{4}$, alkohol, $\mathrm{NaOH}$, $\mathrm{Na}_{2} \mathrm{~S}_{2} \mathrm{O}_{3}, \mathrm{HCl}, \mathrm{HNO}_{3}, \mathrm{HClO}_{4}$, akuades dan larutan lainnya.

\section{Persiapan Bahan}

Ikan madidihang diperoleh dari pasar Bastiong, Kota Ternate Selatan dalam keadaan segar, selanjutnya dicuci (menghilangkan lendir, darah dan kotoran), disiangi (dibuang isi perut, kulit, dan kepala), dan difilet untuk memisahkan daging dan tulang. Selanjutnya, daging ikan dipotong-potong dadu, dicuci 
kembali, ditiris dan digiling menggunakan grinder hingga menghasilkan lumatan daging ikan.

\section{Proses Pembuatan}

Proses pembuatan: Daging ikan lumat diambil sebanyak $250 \mathrm{~g}$ dan dicampur dengan tapioka sesuai perlakuan dengan konsentrasi $0 \%\left(\mathrm{PO}_{1}\right.$, kontrol), 25\% $\left(\mathrm{PO}_{2}\right), 50 \%\left(\mathrm{PO}_{3}\right)$, dan $75 \%\left(\mathrm{PO}_{4}\right)$, kemudian ditambahkan bumbubumbu basah (yang sudah dihaluskan) seperti $20 \mathrm{~g}$ bawang merah, $15 \mathrm{~g}$ bawang putih, $5 \mathrm{~g}$ lengkuas, $100 \mathrm{ml}$ santan kelapa, dan $5 \mathrm{~g}$ garam, selanjutnya semua bahan tersebut diadon dan dicampur merata hingga homogen, dicetak dan dikukus selama \pm 10 menit hingga matang merata, didinginkan dan dipanggang sebelum dilakukan pengujian dan analisis.

\section{Pengujian dan Analisis}

Pengujian dan analisis yang dilakukan terhadap produk otak-otak dilakukan dalam 2 tahapan yaitu uji sensori dan analisis proksimat. Pengujian sensori merupakan penilaian secara subyektif menggunakan skala hedonik 1 (amat sangat tidak suka) sampai dengan 9 (amat sangat suka) sesuai dengan SNI (2006), yang dilakukan oleh 30 orang panelis tidak terlatih, untuk menilai 12 sampel guna menentukan tingkat penerimaan pada atribut kenampakan, warna, rasa, dan tekstur produk. Sementara analisis proksimat meliputi kadar air (SNI, 2006), abu (SNI, 2006), protein total (SNI, 2006), lemak total (SNI, 2006), dan karbohidrat (by difference) serta nilai rendemen.

\section{Analisis Data}

Rancangan percobaan untuk persiapan
sampel dan analisis data proksimat
menggunakan Rancangan Acak Lengkap
(RAL) faktor tunggal yaitu konsentrasi tapioka
$(0 \%, 25 \%, 50 \%$ dan $75 \%$ ) dengan 3 kali
ulangan pada setiap perlakuan dan apabila
secara kolektif berpengaruh secara signifikan
maka akan dilakukan uji beda antar perlakuan
menggunakan uji Duncan Multiple Range Test
(Hanafiah, 2014), sedangkan untuk penilaian
atribut sensori menggunakan uji Kruskal-Wallis
(Sugiyono, 2015).

\section{HASIL DAN PEMBAHASAN}

\section{Mutu sensori}

Proses pengujian mutu sensori dilakukan menggunakan indera manusia untuk menentukan sifat organoleptik dan kenikmatan produk, berdasarkan reaksi dari lima indera, yang membantu untuk mengetahui karakteristik fisik bahan (Balázs, 2012). Pengujian skala hedonik adalah uji tingkat kesukaan terhadap suatu produk berdasarkan preferensi konsumen untuk satu produk terhadap produk lainnya (Actia, 2001).

Uji sensori ditinjau dari dua perspektif yang berbeda yaitu produk dan konsumen. Penilaian produk misalnya uji perbedaan untuk kontrol mutu, pemodelan penentuan umur simpan, klasifikasi kelas dan indeks mutu, sedangkan penilaian konsumen fokus pada mutu produk, nutrisi, lingkungan atau faktor individu yang mempengaruhi kemampuan presepsi terhadap produk seperti budaya atau kondisi fisiologis (Valentin dkk., 2012).

Respon panelis terhadap atribut sensori produk otak-otak seperti pada Tabel 1, yang menunjukkan nilai atribut kenampakan 5,026,30; tekstur 4,96-6,24; aroma 5,40-6,40 serta rasa 5,12-6,54, dan kisaran nilai atribut sensori untuk kenampakan, aroma dan rasa berada pada kategori netral sampai dengan agak suka, sedangkan untuk tekstur pada kategori agak tidak suka sampai agak suka. Hasil uji Kruskal Wallis nilai atribut sensori menunjukkan bahwa penggunaan tapioka dengan konsentrasi yang berbeda secara statistik tidak berpengaruh terhadap atribut kenampakan, tekstur, aroma dan rasa produk otak-otak ikan madidihang pada $\alpha=0,05$. 
Tabel 1. Nilai Atribut Sensori Otak-otak Ikan Madidihang

\begin{tabular}{lcccc}
\hline \multicolumn{1}{c}{ Atribut Sensori } & $\mathrm{PO}_{1}$ & $\mathrm{PO}_{2}$ & $\mathrm{PO}_{3}$ & $\mathrm{PO}_{4}$ \\
\hline Kenampakan & $5,56^{\mathrm{a}} \pm 0,79$ & $6,12^{\mathrm{a}} \pm 0,47$ & $6,30^{\mathrm{a}} \pm 0,08$ & $5,02^{\mathrm{a}} \pm 0,78$ \\
Tekstur & $5,59^{\mathrm{a}} \pm 0,94$ & $6,08^{\mathrm{a}} \pm 0,59$ & $6,24^{\mathrm{a}} \pm 0,71$ & $4,96^{\mathrm{a}} \pm 0,95$ \\
Aroma & $5,40^{\mathrm{a}} \pm 0,66$ & $6,40^{\mathrm{a}} \pm 0,11$ & $6,17^{\mathrm{a}} \pm 0,76$ & $5,40^{\mathrm{a}} \pm 0,72$ \\
Rasa & $5,88^{\mathrm{a}} \pm 1,09$ & $6,54^{\mathrm{a}} \pm 0,45$ & $6,46^{\mathrm{a}} \pm 0,74$ & $5,12^{\mathrm{a}} \pm 0,65$ \\
\hline
\end{tabular}

Ket.: Angka dengan huruf yang sama pada baris yang sama, tidak berbeda nyata pada $\alpha=0,05$ $\mathrm{PO}_{1}=0 \% ; \mathrm{PO}_{2}=25 \% ; \mathrm{PO}_{3}=50 \%$ dan $\mathrm{PO}_{4}=75 \%$ konsentrasi tapioka

Mutu makanan dipengaruhi oleh beberapa faktor seperti rasa, tekstur, gizi dan mikrobiologis akan tetapi sebelum faktor-faktor tersebut tampilan visual dan warna akan menjadi faktor penentu yang dipertimbangkan lebih dulu. Kenampakan atau tampilan merupakan ciri pertama yang dirasakan oleh indera dan berperan penting dalam memilih dan mengidentifikasi makanan dengan melihat visualisasi makanan berupa warna, bentuk, ukuran, kilap, kusam dan transparan (Sharif dkk., 2017). Tampilan suatu makanan menstimulasi keinginan dan penerimaan konsumen terhadap makanan melalui ekspresi kesukaan dan kesenangan.

Penggunaan tapioka pada konsentrasi 25\% dan 50\% menghasilkan tampilan produk otak-otak menjadi lebih kenyal, padat, serta warna yang baik, namun ketika ditambahkan dengan konsentrasi yang berlebihan (75\%), mengakibatkan ketidaksukaan konsumen terhadap kenampakan produk yang dihasilkan, yang ditunjukkan nilai kenampakan berkisar antara 5,02-6,30 dengan nilai tertinggi pada $\mathrm{PO}_{3}$ (50\%) dan terendah pada $\mathrm{PO}_{4}(75 \%)$.

Tekstur merupakan faktor penentu lain penerimaan konsumen terhadap suatu produk melalui visual, auditori dan sentuhan, yang mengambarkan kondisi fisik, konsistensi dan struktur bahan (Balázs, 2012). Tekstur merupakan karakteristik terpenting yang mempengaruhi kualitas produk (Huda dkk., 2010). Penentuan tekstur makanan dapat dilakukan menggunakan jari, gigi, dan langitlangit mulut sehingga terdeteksi kekerasan, keempukan dan mudah dikunyah suatu makanan (Meilgaard dkk., 1999).

Penambahan konsentrasi tapioka pada pembuatan produk otak-otak, membantu pembentukan tekstur kenyal, jernih dan keras, karena kandungan amilosa dan amilopektin pada tapioka yang mudah menyerap air dan tergelatinisasi akibat proses pemanasan. Gelatinisasi pati dalam air merupakan proses terlepasnya ikatan antar molekul amilosa dan amilopektin akibat pemanasan, sehingga menghasilkan larutan kental, membentuk gel dan mengeras (Tako dkk., 2014). Nilai penerimaan tekstur produk otak-otak berada pada kisaran 4,96-6,24, dengan nilai tertinggi pada $\mathrm{PO}_{3}(50 \%)$ dan terendah pada $\mathrm{PO}_{4}(75 \%)$. Hal ini menunjukkan bahwa pada konsentrasi tapioka $75 \%$, menghasilkan produk yang agak keras, kenyal dan sulit digigit, serta dikunyah pada saat pengujian, karena konsentrasi tapioka dengan kandungan amilosa dan amilopektin yang tinggi, sehingga ketika terjadi proses pengukusan mengakibatkan amilosa tergelatinisasi dan mengeras ketika pada suhu normal.

Aroma dan rasa memiliki hubungan erat. Aroma merupakan jenis senyawa aromatik yang bersifat volatil dari makanan akibat proses pengunyahan yang diterima oleh reseptor bau pada rongga hidung, ketika bau yang ditimbulkan menyenangkan, maka respon terhadap makanan yang diuji dikatakan lezat dan enak, selain menentukan tingkat kesukaan terhadap makanan aroma juga berperan dalam keamanan pangan karena dapat digunakan untuk menentukan kesegaran, ketengikan bahkan racun (Sharif dkk., 2017). Nilai aroma produk otak-otak berada pada kisaran 5,40-6,40 dengan nilai tertinggi pada $\mathrm{PO}_{2}(25 \%)$ dan terendah pada $\mathrm{PO}_{1}(0 \%)$. Aroma yang terdapat pada produk otak-otak kemungkinan berasal dari senyawa volatil pada daging ikan, dan ketika ditambahkan dengan garam, bumbubumbu dan tapioka akan meningkatkan selama proses pemasakan.

Atribut rasa melibatkan persepsi bahan setelah larut dalam air liur, minyak atau air oleh reseptor di indera perasa pada permukaan lidah, mulut dan tenggorokan (Sharif dkk., 2017). Rasa makanan oleh indera perasa secara alami, berpengaruh saat makanan dicerna, karena pada dasarnya rasa dalam sistem penginderaan nutrisi, hanya dalam kualitas rasa manis, asin, umami, pahit, dan asam (Boesveldt and Graaf., 2017), selanjutnya dikatakan bahwa rasa memiliki peran sebagai sistem penginderaan nutrisi, selama proses konsumsi. Rasa suatu 
produk menentukan kecepatan mengunyah dan durasi makanan di mulut. Karena rasa sangat mempengaruhi tingkat penerimaan konsumen terhadap suatu makanan.

Rasa produk otak-otak berasal dari daging ikan, bumbu-bumbu dan garam sebagai peningkat rasa. Penambahan konsentrasi tapioka dalam pembuatan produk otak-otak dengan konsentrasi $25 \%$ dan $50 \%$, mengakibatkan peningkatan penerimaan terhadap rasa produk, dan menurun pada pada konsntrasi $75 \%$. Penggunaan-tapioka yang berlebihan sebagai bahan pengikat akan menurunkan rasa produk, hal ini disebabkan tapioka mempuntai rasa yang netral sehingga ketika digunakan sebagai bahan tambahan akan mereduksi rasa bahan lainnya (Patria dkk., 2009).

\section{Komposisi proksimat}

Komposisi proksimat otak-otak ikan Madidihang yang dihasilkan pada konsentrasi tapioka $0 \%, 25 \%, 50 \%$ dan $75 \%$, disajikan pada Tabel 2. Data pada Tabel 2 tersebut menunjukkan bahwa semakin besar konsentrasi tapioka yang ditambahkan mengakibatkan penurunan kadar air, abu, dan protein, sedangkan kadar lemak mengalami penurunan pada konsentrasi tapioka $25 \%$ dan $50 \%$, dan meningkat pada konsentrasi $75 \%$.

Kandungan karbohidrat semakin meningkat akibat semakin besar konsentrasi tapioka yang ditambahkan pada pembuatan produk otak-otak ikan. Analisis sidik ragam menunjukkan bahwa penambahan konsentrasi tapioka berpengaruh sangat nyata terhadap kadar air, abu, protein, dan karbohidrat, sedangkan berpengaruh nyata terhadap kadar lemak produk otak-otak ikan $(\alpha=0,05)$.

Tabel 2. Komposisi Proksimat Otak-otak Ikan Madidihang

\begin{tabular}{lcccc}
\hline Komponen & $\mathrm{PO}_{1}$ & $\mathrm{PO}_{2}$ & $\mathrm{PO}_{3}$ & $\mathrm{PO}_{4}$ \\
\hline K. Air & $69,78^{\mathrm{a}} \pm 0,85$ & $61,88^{\mathrm{b}} \pm 0,37$ & $51,32^{\mathrm{c}} \pm 0,64$ & $46,45^{\mathrm{d}} \pm 0,30$ \\
K. Abu & $1,83^{\mathrm{a}} \pm 0,08$ & $1,28^{\mathrm{b}} \pm 0,03$ & $1,28^{\mathrm{b}} \pm 0,06$ & $0,98^{\mathrm{c}} \pm 0,04$ \\
K. Protein & $26,38^{\mathrm{a}} \pm 0,85$ & $15,76^{\mathrm{b}} \pm 0,80$ & $10,89^{\mathrm{c}} \pm 0,29$ & $5,65^{\mathrm{d}} \pm 0,39$ \\
K. Lemak & $1,25^{\mathrm{a}} \pm 0,07$ & $0,94^{\mathrm{b}} \pm 0,01$ & $0,98^{\mathrm{c}} \pm 0,12$ & $1,56^{\mathrm{cd}} \pm 0,15$ \\
K. Karbohidrat & $0,77^{\mathrm{a}} \pm 0,13$ & $20,15^{\mathrm{b}} \pm 0,56$ & $35,53^{\mathrm{c}} \pm 0,83$ & $45,37^{\mathrm{d}} \pm 0,36$ \\
\hline
\end{tabular}

Ket. Angka dengan huruf yang sama pada baris yang sama, tidak berbeda nyata pada $\alpha=0,05$.

$\mathrm{PO}_{1}=0 \% ; \mathrm{PO}_{2}=25 \% ; \mathrm{PO}_{3}=50 \%$ dan $\mathrm{PO}_{4}=75 \%$ konsentrasi tapioka

Kadar air merupakan salah satu faktor yang sangat penting yang dapat menentukan mutu suatu produk. Nilai kadar air produk otakotak pada kisaran 46,45-69,78\% dengan nilai tertinggi pada produk otak-otak $\mathrm{PO}_{1}$ dan terendah pada $\mathrm{PO}_{4}$. Hal ini karena tapioka memiliki kadar air yang rendah berkisar antara $7,87-8,11 \%$ dengan kandungan pati 72,38 $79,30 \%$ (Nurdjanah dkk., 2013), sehingga ketika ditambahkan pada daging ikan dalam pembuatan adonan akan menyerapkan air pada produk yang dihasilkan. Proses pengukusan pada suhu tinggi mengakibatkan gelatinisasi, karena membengkaknya granula pati menyebabkan lemahnya ikatan amilosa dan amilopektin sehingga terjadi penyerapan air oleh granula pati, dan terlepas selama proses penguapan dan pemanggangan.

Kadar abu adalah sisa bahan anorganik yang tertingggal bila suatu makanan dibakar dengan sempurna didalam suatu tungku pengabuan yang digunakan sebagai indicator jumlah elemen mineral pada suatu bahan (Fennema, 1996; Estiasih et al., 2015). Nilai kadar abu produk otak-otak pada kisaran 0.98$1.83 \%$ dengan nilai tertinggi pada produk otakotak $\mathrm{PO}_{1}$ dan terendah pada $\mathrm{PO}_{4}$, ini menunjukkan semakin besar konsentrasi tapioka sebagai bahan pengikat, mengakibatkan penurunan kandungan mineral produk otakotak. Hal ini diduga akibat rendahnya kadar abu tapioka \pm 0,17-0,27\% (Nurdjanah dkk., 2017), dibandingkan dengan daging ikan madidihang, sehingga ketika ditambahkan dalam konsentrasi berlebihan mengakibatkan penurunan kadar abu produk.

Protein merupakan suatu zat makanan yang paling penting bagi tubuh karena berfungsi sebagai zat pengatur dan pembangun, selain itu protein juga berfungsi sebagai bahan bakar dalam tubuh. Nilai kadar protein produk otak-otak pada kisaran 5,65-26,38\% dengan nilai tertinggi pada produk otak-otak $\mathrm{PO}_{1}$ dan terendah pada $\mathrm{PO}_{4}$ yang menunjukkan semakin besar penambahan konsentrasi tapioka, mengakibatkan penurunan kadar protein, hal ini disebabkan kandungan protein pada tapioka rendah $\pm 0,8 \%$ (Oladunmoye dkk., 2014). Hasil 
yang sama juga ditunjukkan pada produk otakotak ikan sapu-sapu, yang mengalami penurunan kadar protein ketika ditambahkan tepung sebagai bahan pengikat (Nurjanah, 2005). Kadar protein produk otak-otak, terukur sebagai kandungan nitrogen bahan yang berasal daging ikan, santan dan tapioka.

Lemak dan minyak merupakan zat makanan yang sangat penting untuk menjaga kekebalan dan kesehatan tubuh manusia (Zevenbergen dkk., 2009). Nilai kadar lemak produk otak-otak pada kisaran 0,94-1,56\% dengan nilai tertinggi pada produk $\mathrm{PO}_{4}$ dan terendah pada $\mathrm{PO}_{2}$. Kadar lemak produk otakotak ikan mengamali penurunan nilai dengan semakin besar penambahan konsentrasi tapioka, karena tapioka merupakan bahan kering yang rendah lemak $\pm 1,0-2,5 \%$ (Oladunmoye dkk., 2014; Morgan dan Choct, 2016), mampu menyerap lemak dari daging ikan, dan membentuk sifat pengemulsi saat dicampurkan dengan santan. Proses pengukusan dan pemanggangan juga mengakibatkan kandungan lemak bahan terlepas bersama uap air akibat ada panas.

Nilai karbohidrat produk otak-otak pada kisaran 0,77-45,37\% dengan nilai tertinggi pada produk otak-otak $\mathrm{PO}_{4}$ dan terendah pada $\mathrm{PO}_{1}$, hal ini menunjukkan bahwa karbohidrat bahan mengalami peningkatan akibat penambahan konsentrasi tapioka. Besarnya nilai karbohidrat pada produk otak-otak berasal dari tapioka digunakan sebagai bahan pengisi, karena kandungan karbohidrat pada tapioka $\pm 87,8 \%$ dan pati $\pm 84,5 \%$, serta glukosa $1,5 \%$ (Oladunmoye dkk., 2014).

\section{KESIMPULAN}

Penambahan konsentrasi tapioka tidak berpengaruh terhadap mutu sensori, namun berpengaruh terhadap kandungan nutrisi produk otak-otak ikan madidihang yang dihasilkan. Mutu sensori produk otak-otak yang ditambahkan konsentrasi tapioka yaitu atribut kenampakan 5,02-6,30; tekstur 4,96-6,24; aroma 5,40-6,40 serta rasa 5,12-6,54, dengan kandungan nutrisi pada kadar air 46,45$69,78 \%$; abu $0,98-1,83 \%$; protein 5,65-26,38\%; lemak $0,94-1,56 \%$ dan karbohidrat 0,77 $45,37 \%$. Hasil ini menunjukkan bahwa formulasi bahan dalam pembuatan produk menjadi faktor penentu yang mempengaruhi kandungan nutrisi produk yang dihasilkan.

\section{DAFTAR PUSTAKA}

Actia. 2001 Sensory Evaluation - Guide of Good Practise. Actia and Actia Centre. Paris. France.

Balázs, S. P. 2012. Sensory Evaluation in Food Industry. Szechenyi 2020. Magtarorszag Kormanya. Europian Union.

Boesveldt, S., and de Graaf, K. 2017. The Differential Role of Smell and Taste For Eating Behavior. Perception 2017. 46 (34): $\quad 307-319 . \quad$ DOI:10.1177/ 0301006616685576

Estiasih, T., Putri, W. D. R., dan Widyastuti, E. 2015. Komponen Minor dan Bahan Tambahan Pangan. Bumi Aksara. Jakarta.

Fennema, O. R. 1996. Food Chemistry. $3^{\text {rd }}$ Ed. University of Wisconsin Madison. New York.

Hadinoto, S., dan Idrus, S. 2018. Proporsi dan Kadar Proksimat Bagian Tubuh Ikan Tuna Ekor Kuning (Thunnus albacares) dari Perairan Maluku. Majalah Biam. 14(02): 51-57. Available online at: ejournal.kemenperin.go.id/bpbiam.

Hanafiah, K. A. 2014. Rancangan Percobaan Teori dan Aplikasi. Ed. 3, Cetakan 15. Rajawali Press. Jakarta

Huda, N., Shen, Y. H., Huey, Y.L., Ahmad, R., and Mardiah, A. 2010. Evaluation of Physico-Chemical Properties of Malaysian Commercial Beef Meatballs. American Journal of Food Technology. 5: 13-21. DOI: 10.3923/ ajft.2010.13.21.

Jamil, S. N. A. 2016. Pengaruh Penambahan Tepung Karagenan Terhadap Sifat Kimia Otak-otak Ikan Gabus (Ophiocephalus striatus). Samakia: Jurnal Ilmu Perikanan. 7(1): 12-21.

Karim, M., Susilowati, M., dan Asnidar. 2013. Analisis Tingkat Kesukaan Konsumen Terhadap Otak-otak Dengan Bahan Baku Ikan Berbeda. Jurnal Balik Diwa. 4 (1): 25-31.

Lekahena, V. N. J. 2015. Pengaruh Subtitusi Daging Ikan Madidihang dengan Rumput Laut Kappaphycus alvarezii terhadap Komposisi Gizi Bakso Ikan Madidihang. Agrikan: Jurnal Ilmiah Agribisnis dan Perikanan. 8(2): 92-98.

Meilgaard M., Civille, G. V., and Carr, B. T. 1999. Sensory Evaluation Techniques. 3rd Ed. CRC Press, Florida. 
Morgan, N. K., and Choct, M. 2016. Cassava: Nutrient composition and nutritive value in poultry diets. Review Article. Animal Nutrition 2: 253-261. http://dx.doi.org/10.1016/j.aninu.2016.0 $\underline{8.010}$

Nurdjanah, S., Hasanudin, U., Yuliana, N., and Silvianti, D. 2016. Physicochemical of Cassava Stach Produced by Ittara-a small scale tapioca industry: A case study at PD Semangat Jaya Lampung. USIFS Conference Proceedings, 2016 (2), pp. 158-165. ISSN ISBN9786920860107.

Nurjanah., Abdullah, A., Naibaho, I., Kartikayani, D., Nurilmala, M., Yusfiandayani, Y., and Sondita, M. F. A. 2020. Fish quality and nutritional assessment of yellowfin tuna (Thunnus albacares) during low temperature storage. IOP Conf. Series: Earth and Environmental Science, 404, 012074, pp. 1-10. doi:10.1088/17551315/404/1/ 012074

Nurjanah., Nitibaskara, R. R., dan Madiah, E. 2005. Pengaruh Penambahan Bahan Pengikat terhadap Karakteristik Fisik Otak-otak Ikan Sapu-sapu (Liposarcus pardalis). Buletin Teknologi Hasil Perikanan. 8 (1): 1-11.

Oladunmoye, O. O., Aworh O. C., MaziyaDixon, B., Erukainure, O. L., and Elemo. G. N. 2013. Chemical and functional properties of cassava starch, durum wheat semolina flour, and their blends. Food Science and Nutrition. 2 (2): 132138.

Patria, A., Basyamfar, R. A., dan Eryani, D. 2009. Sifat Fisik Surimi Ikan Sardin (Sardimela longiceps) dengan jenis bahan pengikat (Tapioka dan Terigu) dan Variasi Konsentrasi Sodium Tripolifosfat. Teknologi dan Industri pertanian Indonesia. 2:26-30.

Poernomo, D., Suseno, S. H., Supriyono, E., Arifah, F., Sriwahyuni, D., Rahmadhiani, P., Ichwalludin, M., dan Sinta, N. N. 2019. Pengolahan Ikan Tuna menjadi Sambal Ikan Tuna (Sauna) Sebagai Produk Bernilai Jual Tinggi di Desa Sukaraja, Kabupaten Sukabumi, Jawa Barat. Jurnal Pusat Inovasi Masyarakat 1(1): 50-58.

Putra, D. A. P., Agustini, T. W. dan Wijayanti, I. 2015. Pengaruh Penambahan Karagenan Sebagai Stabilizer Terhadap
Karakteristik Otak-otak Ikan Kurisi (Nemipterus nematophorus). Jurnal Pengolahan dan Bioteknologi Hasil Perikanan. 4(2):1-10. http://www.ejournals1.undip.ac.id/index.php/ jpbhp

Ramlawati, R. dan Ramli, A. 2018. Pembuatan Berbagai Produk Olahan Ikan Bagi Kelompok Tani Nelayan di Kecamatan Sanrobone Kabupaten Takalar. Jurnal IPA Terpadu. 1(2): 86-95.

Sharif, M. K., Butt, M. S., Sharif, H. R., and Nasir, M. 2017. Sensory Evaluation and Consumer Acceptability. In book: Handbook of Food Science and Technology - Chapter 14: Sensory Evaluation and Consumer Acceptability. UAF Press, Faisalabad, Pakistan.

SNI [Standar Nasional Indonesia]. 2006. SNI: 012346-2006. Petunjuk Pengujian Organoleptik dan Sensorik. Badan Standarisasi Nasional Indonesia. Jakarta

SNI [Standar Nasional Indonesia]. 2006. SNI: 01-2354.1-2006. Cara Uji Kimia Bagian 1: Penentuan Kadar Abu Pada Produk Perikanan. ICS. 67.120.30 Badan Standarisasi Nasional Indonesia. Jakarta

SNI [Standar Nasional Indonesia]. 2006. SNI: 01-2354.2-2006. Cara Uji Kimia Bagian 2: Penentuan Kadar Air Pada Produk Perikanan. ICS. 67.120.30 Badan Standarisasi Nasional Indonesia. Jakarta.

SNI [Standar Nasional Indonesia]. 2006. SNI: 01-2354.3-2006. Cara Uji Kimia Bagian 3: Penentuan Kadar Lemak Pada Produk Perikanan. ICS. 67.120.30 Badan Standarisasi Nasional Indonesia. Jakarta.

SNI [Standar Nasional Indonesia]. 2006. SNI: 01-2354.4-2006. Cara Uji Kimia Bagian 4: Penentuan Kadar Protein Pada Produk Perikanan. ICS. 67.120.30 Badan Standarisasi Nasional Indonesia. Jakarta.

Sugiyono. 2015. Statistik Nonparametris untuk Penelitian. Penerbit Alfabeta. Bandung.

Tako, M., Tamaki, Y., Teruya, T., and Takeda, Y. 2014. The Principles of Starch Gelatinization and Retrogradation. Food and Nutrition Sciences, 5: 280-291. http://dx.doi.org/10.4236/fns.2013.5303 5

Talib, A. 2011. Uji Tingkat Kesukaan Nugget Ikan Madidhang (Thunnus albacares) Dengan Bahan Pengisi Yang Berbeda. Agrikan: Jurnal Ilmiah Agribisnis dan Perikanan. 4(1): 58-64. 
Transformasi [Center for Public Policy Transformation]. 2019. Laporan: Napak Tilas Perikanan Provinsi Maluku Utara. 4 hal. Oktober 2019. Laporan_Maluku_Utara_Fixed_compres sed.pdf

Valentin, D., Chollet, S., Lelièvre, M., and Abdi, H. 2012. Quick and dirty but still pretty good: A review of new descriptive methods in food science. International Journal of Food Science and Technology. 47(8): 1563-1578.

Zevenbergen, H., de Bree, A., Zeelenberg, M., Laitinen, K., van Duijn, G., and Flöter E. 2009. Foods with a High Fat Quality Are Essential for Healthy Diets. Annals of Nutrition and Metabolism. 54 (suppl. 1): 15-24. DOI: $10.1159 / 000220823$ 